\title{
Researching of physicochemical and structural-phase transformations in carbothermal titanomagnetite concentrates reduction for sustainable development of raw materials base of metallurgical enterprises
}

\author{
Dmytro Baboshko ${ }^{1, *}$, Levan Saithareiev ${ }^{1}$, Hennadiy Hubin ${ }^{2}$, Oksana Vodennikova ${ }^{3}$, and Ihor Skidin ${ }^{1}$ \\ ${ }^{1}$ Kryvyi Rih National University, Ferrous metals metallurgy \& foundry Department, Kryvyi Rih, Ukraine \\ ${ }^{2}$ Kryvyi Rih National University, Occupational safety \& civil security Department, Kryvyi Rih, Ukraine \\ ${ }^{3}$ Zaporizhzhia National University, Metallurgy Department, Zaporizhzhia, Ukraine
}

\begin{abstract}
This study displays results of carbothermal reduction researches of titanomagnetite concentrate obtained during complex apatite-titanomagnetite-ilmenite ore dressing. The mineral composition was analyzed and the structural and textural features of the titaniferous ore of Kropivensky deposit and the titanomagnetite concentrate obtained from it were revealed. The mechanism of solid-phase carbothermal the titanomagnetite concentrate reduction is investigated. Temperature-time parameters have been discovered to ensure the formation of both products with the maximum yields of iron and titania from metal and slag-phase during titanomagnetite concentrate reduction. One-stage resource-saving flow chart of titanomagnetite concentrate processing with mass fraction up to $25 \% \mathrm{TiO}_{2}$ is developed.. It allows to obtain two marketable products: granular cast iron $(92-96.5 \% \mathrm{Fe}, 3.4-3.7 \% \mathrm{C}, 0.5 \% \mathrm{~V})$ in $57 \%$ yield and titaniferous slag $\left(50-55 \% \mathrm{TiO}_{2}\right.$, up to $\left.7.4 \% \mathrm{FeO}\right)$ in $43 \%$ yield.
\end{abstract}

\section{Introduction}

Within the framework of the stable metallurgy development program, the team of the Ferrous metals metallurgy and foundry Department of Kryvyi Rih National University scientists deals with the following important tasks: improving the hot-rolled steel plate technology [1] and determining the optimal parameters for the electrical treatment of foundry steels during casting [2]. Another area of research is the development of recommendations for the complex titanium ores involvement in processing. [3]

The rapid development of the metallurgical complex has led to a reducing of quality iron ore reserves amount. In the near future, they will be replaced by complex ores that can meet the needs of ferrous and non-ferrous metallurgy companies. Ukraine has significant complex ore of apatite-titanomagnetite-ilmenite composition reserves. The technologies of their preparation for metallurgical conversion make it possible to obtain basic ilmenite and apatite commodity concentrates and, in addition, titanomagnetite, which can contain $46-52 \%$ of $\mathrm{Fe}$ and $20-25 \%$ of $\mathrm{TiO}_{2}$.

Titanomagnetite concentrate is not currently processed by existing metallurgical enterprises in Ukraine, but it is a promising raw material for the sustainable development of cast iron, steel, titania $\left(\mathrm{TiO}_{2}\right)$ and metallic titanium. The development and implementation of processing technology for this concentrate will allow the storage of valuable mineral components in the waste heaps. Extant technologies include the use of two-stage processing, which consists of pre-reduction and ore-thermal electric melting, followed by separation into industrial products. These technologies are characterized by high energy consumption and environmental hazards. Therefore, research with the discovering and justification of technical and technological solutions for the processing of titanomagnetite concentrates with a high content of $\mathrm{TiO}_{2}$ goal is relevant and important for the sustained development of metallurgy.

In research works [4-7], a number of experiments were conducted on solid-phase reduction of titanomagnetite concentrates with mass fraction of $\mathrm{Fe}$ $56.5-64.5 \%$ and up to $16.7 \% \mathrm{TiO}_{2}$. It has been shown that slag with a wide range of chemical composition from 15.4 to $62.5 \%$ of $\mathrm{TiO}_{2}$ were obtained after their reduction. This is an important basis for studying the iron-containing and titaniferous phases formation mechanism, as well as the allocation of $\mathrm{Fe}$ and $\mathrm{Ti}$ between them. The analysis of those studies` results does not allow us to completely determine the peculiarities of the structural-phase titanomagnetite transformations at different temperature-time parameters of the carbothermal reduction process. In addition, the titanomagnetite concentrates reduction process with a $\mathrm{TiO}_{2}$ mass fraction of $20-25 \%$ has not been studied. 
For carbothermal reduction process, a titanomagnetite concentrate obtained after the apatitetitanomagnetite-ilmenite ore dressing of the Kropivensky deposit was used, having the following composition, mass fraction,\%: $45.5 \mathrm{FeO} ; 23.0 \mathrm{Fe}_{2} \mathrm{O}_{3} ; 22.03 \mathrm{TiO}_{2} ; 1.5$ $\mathrm{SiO}_{2} ; 1.2 \mathrm{Al}_{2} \mathrm{O}_{3} ; 0.26 \mathrm{CaO} ; 3.4 \mathrm{MgO} ; 0.42 \mathrm{MnO} ; 0.516$ $\mathrm{V}_{2} \mathrm{O}_{5} ; 0.04 \mathrm{Cr}_{2} \mathrm{O}_{3}[8,9]$.

Researched ore is low-concentrated, sometimes contain schlier with 1-2 m capacity of high-concentrated varieties. The total content of ore minerals does not exceed $10 \%$. The ore has an apatite-titanomagnetiteilmenite composition with variations in the ratio of titanomagnetite / ilmenite from $1 / 1$ to $1 / 5$. The amount of apatite is $1-3 \%$. The ores of the deposit are characterized by a $\mathrm{Fe} / \mathrm{TiO}_{2}$ ratio from 1.5 to 4.0 .

A defining characteristic of the magmatic process that has led to the titanium ores formation is the fact that minerals are being formed under conditions of constant change in the chemical composition of the residual melt and the individual components in it. In addition, differentiation (separation) of the melt and the arrival of new magma portions can occur. This creates even more complicated crystallization conditions, which are accompanied by the melting of previously formed minerals grains and even their complete melting and digestion. Lowering the temperature in the magmatic cell can lead to the separation of mineral phases already at the solid solution stage, such as ilmenite, as well as $\mathrm{Mg}-$ $\mathrm{Al}$ and $\mathrm{Ti}$ - spinels in magnetite. Sometimes magnetite in pyroxene and others. The peculiarity of all structures of the solid solution decomposition is a very small sized inclusions of one mineral in another $(1-2 \mu \mathrm{m})$, which in the future, in the industrial ores processing leads to different technological difficulties.

Titanomagnetite is the predominant ore mineral in the ore deposit, in some samples its mass fraction can be up to $13.5 \%[10,11]$.

The following research methods were used: microscopy, spectral, structural-textural and X-ray fluorescence analysis.

For roasting and sintering concentrate by method ore coarsening charge, following materials were used: combined bentonite and FERROFORM polymer, flux additive $\mathrm{CaF}_{2}$, and reductant graphite with minimal mineral content.

\section{Results and discussions}

In the study of polished sections under the microscope the titanomagnetite unusualness is noticeable, it is more similar to ilmenite in optical characteristics. If these minerals are separated, in the form of isolated grains, it is difficult to distinguish them. They are easier to distinguish in joint inclusions - by a noticeable reddish tint in the color of titanomagnetite (Fig. 1, a, b). In addition, ilmenite appears to be lighter, which is most likely due to the $\mathrm{Fe}_{2} \mathrm{O}_{3}$ impurity in its composition.

In some grains of titanomagnetite under the microscope, the lamellar ilmenite inclusions in the form of decomposition structures of a solid solution are easy to identify (Fig. 1, c, d). The partial oxidation and leaching of the magnetite component of titanomagnetite under the weathering bark on gabbro-peridotites impact seems to present a true picture of the titanomagnetite grains structure and composition. The study of such ore samples using a microscope made it possible to characterize the titanomagnetite under study, to understand its nature and to develop technologies for the mechanical ore dressing and the subsequent heat treatment of titanomagnetite concentrate.
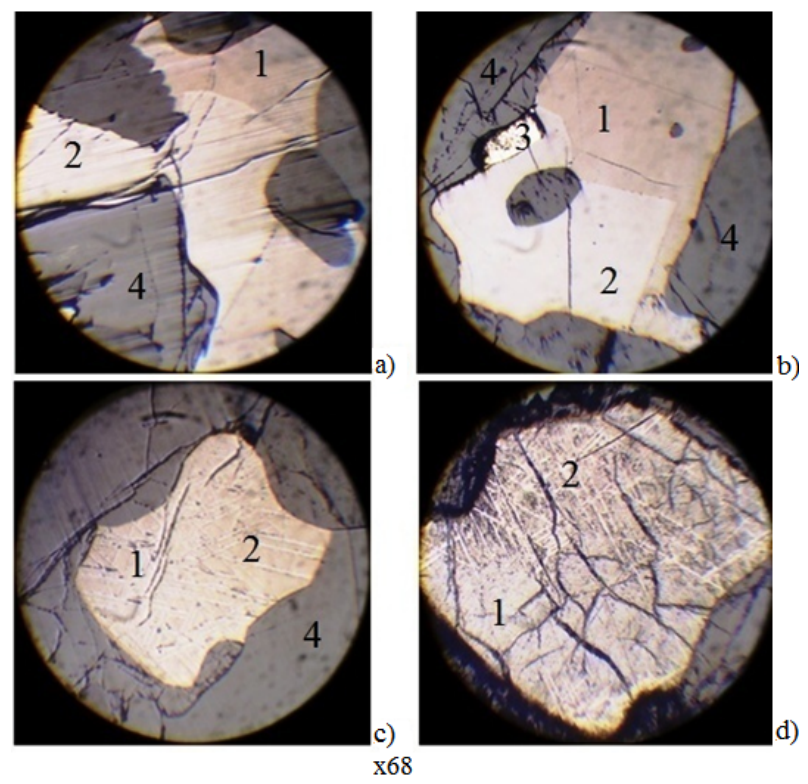

Fig. 1. Theilmenite and titanomagnetite ratio in joint inclusions: a) morphology of titanomagnetite and ilmenite grains;

b) idiomorphism of ilmenite, apatite and sulfide compared to later titanomagnetite; c) lamellar inclusions of ilmenite in titanomagnetite; d) homogeneous titanomagnetite (lower part of the grain), which fades into decay structures with ilmenite plates (upper part of the grain). 1 - titanomagnetite (creamy with a reddish tint), $2-$ ilmenite (white with a grayish tint), 3 iron sulfides (white), 4 - apatite and silicates (different shades of gray).

Microscopy revealed that the grains of titanomagnetite, separated in space, have almost the same size (from $0.03 \mathrm{~mm}$ to $0.6 \mathrm{~mm}$ ) as ilmenite, and are often with it in the fusion (Fig. 2, a, b, c) [12].

Single grains have a homogeneous (homogeneous) structure. Most often they are an aggregate of two or more mineral phases. They coalesce at a very thin submicron level, being elements of solid solution decomposition structures. Therefore, the term "titanomagnetite" is a fairly conditional term. Separate grains (and essentially aggregates of two or four mineral phases), whose chemical composition is determined by the $\mathrm{FeO}, \mathrm{TiO}_{2}$ and $\mathrm{Fe}_{2} \mathrm{O}_{3}$ content, are the titanomagnetits of this deposit. They have high magnetic characteristics. These grains are characterized by the different mineral phases' presence: magnetite, ilmenite, and Al-Mg spinel in small quantities, which are formed after the collapse of the solid mortar. The ratio of these phases in titanomagnetite grains is different.

The magnetite forms the basis of the grain matrix into which the lamellar ilmenite or ulvospinel excretions are immersed and the micro-grain "relict-ilmenite" 
(Fig. 2). The lamellar isolates of ulvospinel generally have a thickness of up to 2-3 microns. Single titanomagnetite grains have lamellar isolates of ilmenite or ulvospinel up to 8-10 microns in size. At the same time there are grains of titanomagnetite with different saturation structure and size of secretions (plates) of ilmenite or ulvospinel (Fig. 1, c, d and 2, a, b). The orientation of the plates according to the octahedral separation in magnetite is characteristic of titanomagnetite, often with the formation of lattice structures (Fig. 2, a).

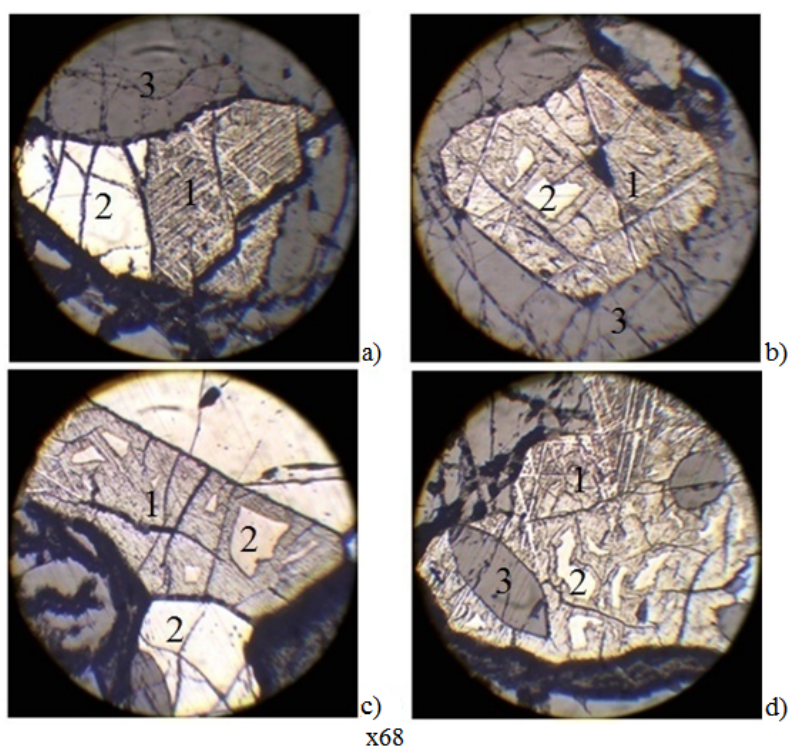

Fig. 2. Features of the titanomagnetite grains structure a) ore grain: left - ilmenite, right - lattice structure of titanomagnetite; b) octahedral titanomagnetite crystals with solid solution decomposition structure and relict inclusions of ilmenite; c) ilmenite in the form of free grains, relic inclusions and plates in the structure of the solid solution decomposition in the grain of titanomagnetite; d) lamellar ilmenite, semi-melted relict grains of ilmenite, incorporation of apatite crystals into titanomagnetite. 1 - lattice structure of titanomagnetite, 2 ilmenite (light cream), 3 - apatite and silicates (different shades of gray).

The micrograin "relict - ilmenite" is often semialloyed, sometimes they are solitary, but more often concentrated in groups (Fig. 2, b, c, d). The size of micro-grains inclusions is $0.05-0.1 \mathrm{~mm}$. These are micro inclusions its remains "Magnetite" magma beneficiateoned by titanium. The presence of "relict ilmenite" micro grain causes a high (up to $25 \%$ ) content of $\mathrm{TiO}_{2}$ titanomagnetite grains [13].

Titanomagnetite is also characterized by the presence of a higher concentration of $\mathrm{V}$ than in ilmenite. This is due to the fact that Fe has a close crystal-chemical bond with $\mathrm{V}$, and since ilmenite has a smaller proportion of $\mathrm{Fe}$, the concentration of $\mathrm{V}$ in it will be lower.

Based on the study of the morphological structures of apatite-titanomagnetite-ilmenite ore, the classification of titanomagnetite grains is made:

- grains with fine ilmenite in the magnetite matrix ( $\mathrm{Fe}-$ $42.36 \pm 2.18 \%, \mathrm{Ti}-14.47 \pm 0.96 \%)$;

- grains having the structure of uniformly distributed lamellar secretions of ilmenite in the magnetite matrix
$(\mathrm{Fe}-34.25 \pm 1.4 \%, \mathrm{Ti}-11.37 \pm 0.37 \%)$;

- grains having the structure of equally distributed lamellar secretions of ilmenite and separate microgranules of "relict-ilmenite" in the magnetite matrix $(\mathrm{Fe}-31.24 \pm 1.73 \%, \mathrm{Ti}-18.65 \pm 1.08 \%)$.

Analysis of these types of titanomagnetite concentrate grains confirmed their complex structure and showed that the reduction conditions of this concentrate will be significantly different from the reduction parameters of iron-containing magnetite concentrate.

The calculations show that the magnetite matrix of titanomagnetite grain contains up to $34.6 \%$ of $\mathrm{Fe}$, and in the ilmenite particle - up to $15 \%$ of Fe. The different structure of the grains and their elemental composition make it necessary to determine the optimal temperature and time parameters for the reduction of the magnetite matrix and the release of ilmenite, which will achieve the maximum extraction of $\mathrm{Fe}$ and $\mathrm{TiO}_{2}$ in the industrial products.

It is established that the obtained coils have satisfactory characteristics for their further reduction: porosity $-30-35 \%$, compressive strength $-1.32 \mathrm{~kg} /$ pellet (for dry $-2.7 \mathrm{~kg} /$ pellet), reset strength -4.2 times.

The process of carbothermalreduction of coils with a diameter of 10-14 $\mathrm{mm}$ was carried out in the temperature range of $800-1500{ }^{\circ} \mathrm{C}$.

Studies of the pellet's microstructure at different temperature-time parameters of the treatment process showed that the reduction of the titanomagnetite concentrate happened in two temperature-time periods, in which significant physicochemical and structuralphase transformations occur.

In the first period ("low-temperature zone", 800$1000^{\circ} \mathrm{C}$ ) there is a physicochemical transformation of iron-containing silicates (olivine and pyroxene) with the formation of magnetite and its subsequent reduction to $\mathrm{Fe}^{0}$. At $900{ }^{\circ} \mathrm{C}$, solid-phase changes start in titanomagnetite grains. Around the grains appears a dark border of $10-15$ microns thick, characterized by a higher titanium content (Fig. 3, a).

It happens as a result of the restoration of the magnetite matrix of the grain with the formation of $\mathrm{Fe}^{0}$ in the form of droplets less than $0.1 \mu \mathrm{m}$ and its diffusive removal beyond the grain boundary (Fig. 3, b).

At $1000{ }^{\circ} \mathrm{C}$ in volume of pellets solid-phase changes are accelerating. Up to 1 microns of $\mathrm{Fe}^{0}$ appear. With increasing the holding time at this temperature up to 40 $\mathrm{min}$, the intensity of both the reduction of the magnetite matrix in titanomagnetite grains up to $0.06 \mathrm{~mm}$ and the release of $\mathrm{Fe}^{0}$ increases. There is an intense formation of a metal sponge (Fig. 3, c, d). In grains of more than 0.06 $\mathrm{mm}$ in size, the concentration of which is not more than $20 \%$ in the concentrate, solid-phase transformations with separation of Fe do not occur.

In the second thermo-time period ("high-temperature zone", $1000-1300{ }^{\circ} \mathrm{C}$ ), the accumulations of $\mathrm{Fe}^{0}$ continue. Titanomagnetite grains complete the reduction of the magnetite grain matrix. At a temperature of $1200^{\circ} \mathrm{C}$, "relic-ilmenite" and a grid of ilmenite remain in place of the titanomagnetite grains, which are inherited from the structures of decomposition of the solid mortar (Fig. 3, c). 


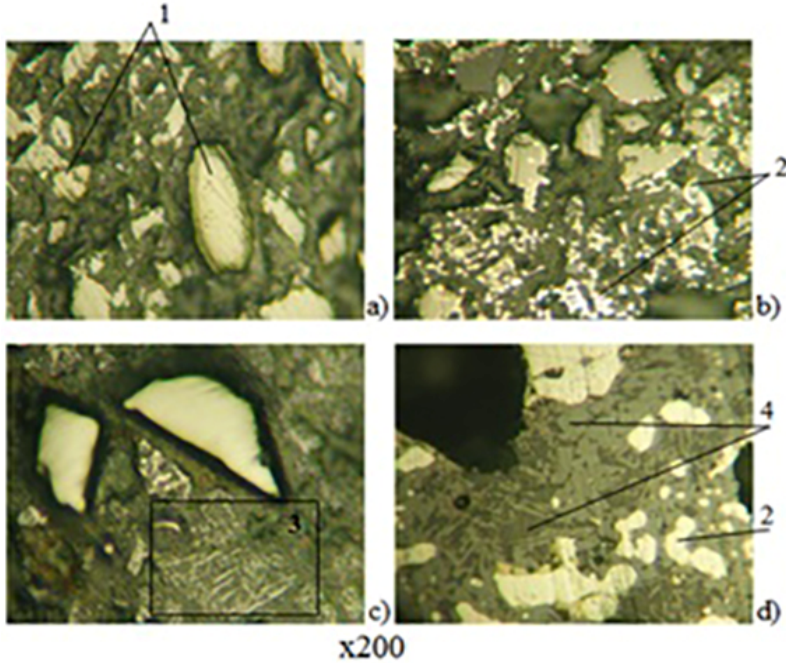

Fig. 3. Structural transformations in coils reduced at 900 $1300{ }^{\circ} \mathrm{C}: 1$ - grains of titanomagnetite (cream color); $2-$ allocation of metallic iron (white color); 3 -ilmenite mesh; 4 slag phase (dark gray and gray).

Exposure for $5-40 \mathrm{~min}$ at $1300{ }^{\circ} \mathrm{C}$ ensures the aggregation of $\mathrm{Fe}^{0}$ clusters up to 0.1-0.2 mm, and shutter speed up to $50 \mathrm{~min}$ - the appearance of regions of $\mathrm{Fe}^{0}$ spherical in diameter up to $2 \mathrm{~mm}$. The slag titanium phase begins to form from the ilmenite mesh. At the endurance of $80 \mathrm{~min}$, the enlargement of $\mathrm{Fe}^{0}$ regions to $3.5 \mathrm{~mm}$ continues, the content of Ti decreases to $2 \%$, but in them there are significant accumulations and separate inclusions of secretions with the content of Ti up to $31 \%$ (Fig. 3, d). The Fe content in the slag phase gradually decreases from $38 \%$ to $25 \%$, and the Ti content increases from $23 \%$ to $39 \%$ (Fig. 3, d) [3].

For maximum extraction of $\mathrm{Fe}^{0}$ and $\mathrm{TiO}_{2}$ into the iron and titanium phase, a complete reduction of the magnetite particle in all grain types is observed, which is observed as a result of holding for $20 \mathrm{~min}$ at $1300{ }^{\circ} \mathrm{C}$ (Table 1), as well as further raising of the temperature to $1500{ }^{\circ} \mathrm{C}$ with holding $5 \mathrm{~min}$. This ensures the reduction of $\mathrm{FeO}$ in the ilmenite particle of the grains. The total degree of metallization of the coils thus increases to $94 \%$.

The reduced product (Fig. 4, a) is a shell-shaped porous formation of a slag phase with a wall thickness of 2-3 $\mathrm{mm}$, and a separated iron phase in the form of spherical particles up to $30 \mathrm{~mm}$ (Fig. 4, b). The slag phase is mainly composed of thin-needle and thin-fiber aggregates of rutile and anatase with up to several micrometers thickness (Fig. 4, c).

Sometimes, in the slag phase, glass inclusions and single residual semi-melted titanomagnetite ore grains of
$0.04 \times 0.07$ and $0.07 \times 0.15 \mathrm{~mm}$ with a $\mathrm{FeO}$ border 1 $3 \mu \mathrm{m}$ thick are observed around them.

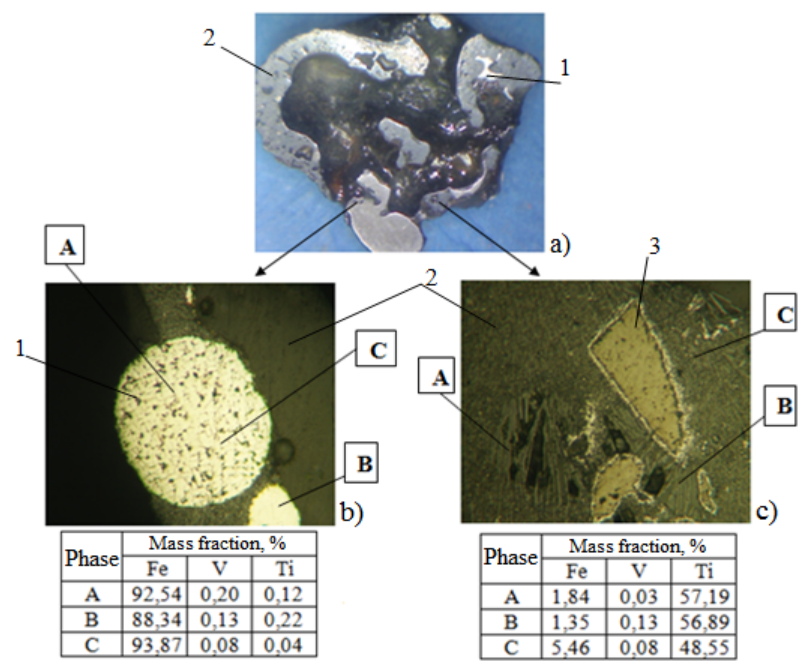

Fig. 4. Reduced product (a), the microstructure (b, c; x200) and the chemical composition (mass, \%) Of the products of reduction: 1 - the separation of metallic iron (white color); 2 slag titanium phase (different shades of gray); 3 - semi-melted grains of titanomagnetite (cream color).

Thus, the parameters of a two-step process for the reduction of titanomagnetite concentrate were determined, which ensure the formation of ironcontaining and titaniferous products with maximum extraction of $\mathrm{Fe}^{0}$ and $\mathrm{TiO}_{2}$ in them. These parameters are: I degree - reduction of the magnetite particle with increasing temperature from $800^{\circ} \mathrm{C}$ to $1300{ }^{\circ} \mathrm{C}$; II degree - restoration of ilmenite particle with increasing temperature from $1300^{\circ} \mathrm{C}$ to $1500{ }^{\circ} \mathrm{C}$.

It should be noted that the formation of metal granules from grains of titanomagnetite is a complex process that happens due to the diffusion of $\mathrm{Fe}^{0}$ microparticles into the intergranular space with its subsequent enlargement due to autogenesis. The forces of adsorption attraction, which are caused by covalent, ionic, polarizing or intermolecular (dispersion) forces, have a significant effect. But several types of these forces are possible at the same time. As the temperature of the process increases, the formation of liquid metal clusters into a spherical shape continues due to coalescence (coagulation). In order to prevent impediments to the coagulation processes of the iron particles and the inhibition of the process of separation of the metallic and slag titaniferous phases, this phase must be converted to a visco-plastic state.

Table 1. Chemical composition of slag phase at the temperature reduction of during $800-1300{ }^{\circ} \mathrm{C}$ temperatures and holding time of 20 and minutes.

\begin{tabular}{|c|c|c|c|c|c|c|}
\hline \multirow{2}{*}{ Holding time } & \multirow{2}{*}{ Series of tests } & \multicolumn{5}{|c|}{ Mass particles, \% } \\
\cline { 2 - 7 } & & $\mathbf{F e}$ & $\mathbf{T i}$ & $\mathbf{V}$ & $\mathbf{S i}$ & $\mathbf{M n}$ \\
\hline \multirow{2}{*}{$20 \mathrm{~min}$} & 1 & 16.7 & 37.58 & 0.58 & 0.42 & 2.42 \\
\cline { 2 - 7 } & 2 & 14.4 & 32.97 & 0.17 & 0.85 & 0.47 \\
\hline \multicolumn{2}{|c|}{ Average } & $15.65 \pm 1.5$ & $35.28 \pm 2.86$ & $0.38 \pm 0.25$ & $0.64 \pm 0.27$ & $1.45 \pm 1.21$ \\
\hline \multirow{2}{*}{$40 \mathrm{~min}$} & 1 & 36.61 & 29.37 & 0.35 & 2.13 & 1.42 \\
\cline { 2 - 7 } & 2 & 42.13 & 30.68 & 0.22 & 1.42 & 1.81 \\
\hline \multicolumn{2}{|c|}{ Average } & $39.37 \pm 3.4$ & $30.03 \pm 0.81$ & $0.29 \pm 0.08$ & $1.78 \pm 0.44$ & $1.62 \pm 0.24$ \\
\hline
\end{tabular}


$\mathrm{T}=800^{\circ} \mathrm{C}$

The first technological area

$$
\mathrm{T}=1300^{\circ} \mathrm{C}
$$

The second technological area

\section{Macrostructure of reducted products}
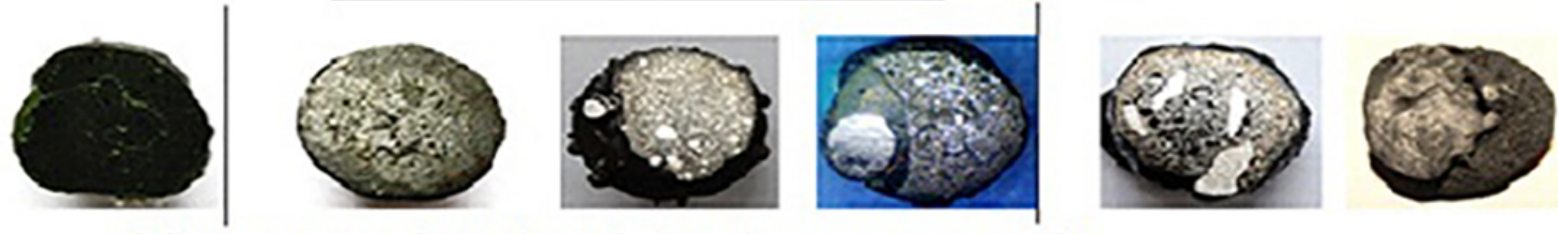

Microstructure of transformed mineral concentrate particles
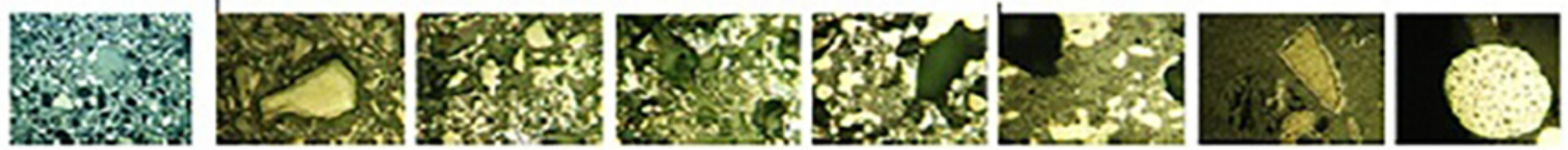

Fig. 5. Chart of structural-phase transformation in the carbothermal reduction of the pelletized titanomagnetite concentrate.

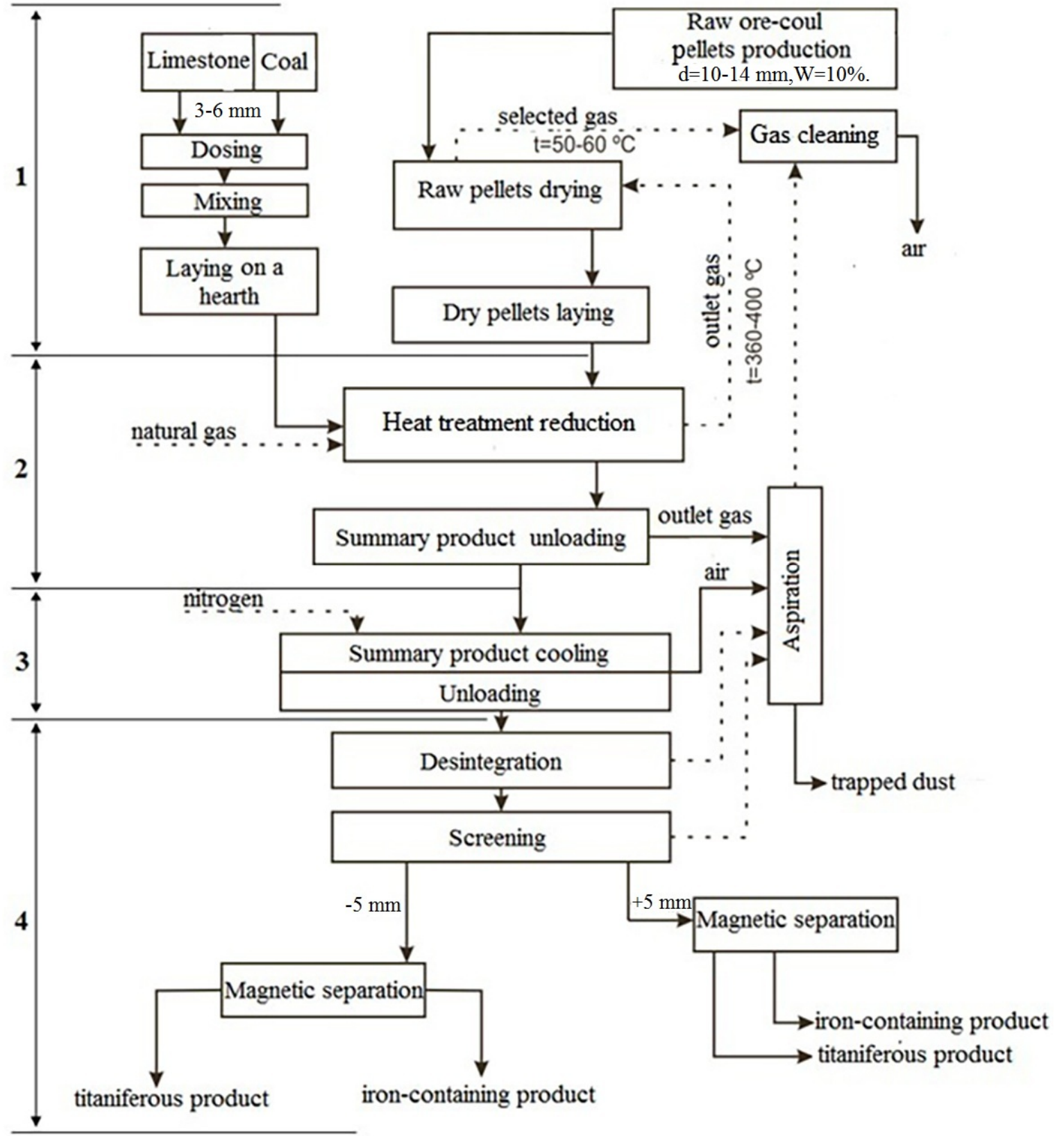

Fig. 6. Flow chart of titanomagnetite concentrate processing. 
It is advisable to carry out the process of two-stage reduction with certain technological parameters in a direct reduction furnace with annular hearth, since the final product is not granulated iron, but granular cast iron. This oven has high operational reliability, economy and environment friendliness.

Chart of structural-phase transformation at certain parameters. The carbothermal reduction of the titanomagnetite concentrate in this furnace is shown in Fig. 5.

According to the results of the research, the working area of the furnace is divided into technological sections (Fig. 5):

section I - loading of the material and its heating from $600{ }^{\circ} \mathrm{C}$ to a temperature of $800{ }^{\circ} \mathrm{C}$;

section II - heating from a temperature of $800{ }^{\circ} \mathrm{C}$ to $1300{ }^{\circ} \mathrm{C}$ with a speed of $20^{\circ} \mathrm{C} / \mathrm{min}$ and holding for $15-20$ min - indirect reduction of the magnetite part of the titanomagnetite grain;

section III - heating from a temperature of $1300^{\circ} \mathrm{C}$ to $1470-1500{ }^{\circ} \mathrm{C}$ at a speed of $50{ }^{\circ} \mathrm{C} / \mathrm{min}$ and holding for 5 min - direct reduction of residual magnetite and $\mathrm{FeO}$ from ilmenite parts of titanomagnetite grains.

The flow chart of titanomagnetite concentrate processing for obtaining marketable products with maximum extraction of $\mathrm{Fe}^{0}$ and $\mathrm{TiO}_{2}$ in them was developed and tested (Fig. 6). This scheme includes the basic production operations: 1 - occlusion of charge materials and their drying, 2 - heating, reduction and melting of coils in a high-temperature unit, 3 - cooling the product; 4 - grinding and dividing of the obtained product into magnetic and non-magnetic fraction.

The yield of the iron-containing fraction was $57 \%$ in the form of cast iron granules $(92-96.5 \% \mathrm{Fe} ; 3.4-3.7 \% \mathrm{C}$, $0.5 \% \mathrm{~V})$, the yield of the slag fraction was $43 \%$ in the form of titaniferous slag with $50-55 \% \mathrm{TiO}_{2}$ and up to $7.4 \% \mathrm{FeO}$.

\section{Conclusions}

As a result of the research, it was discovered that the structural-phase transformations during the carbothermal reduction of the pelletized titanomagnetite concentrate proceeds by the following scheme: physicochemical and structural transformations of the olivine and pyroxene minerals at $800{ }^{\circ} \mathrm{C}$; the beginning of the magnetite matrix reduction of grain with the iron diffusion into the intergranular space at $900{ }^{\circ} \mathrm{C}$; complete reduction of the magnetite component of grain with the ilmenite mesh and "relict-ilmenite" formation at $1200{ }^{\circ} \mathrm{C}$; the emergence of the titaniferous phase as a result of the ilmenite grid reducing and the "relict-ilmenite" at 1300$1500{ }^{\circ} \mathrm{C}$. The parameters of the two-step reduction process of titanomagnetite concentrate, which provide the formation of iron-containing and titaniferous products with maximum extraction of $\mathrm{Fe}^{0}$ and $\mathrm{TiO}_{2}$ in them, are experimentally discovered. I step - magnetite phase reduction with increasing temperature from $800^{\circ} \mathrm{C}$ to $1300{ }^{\circ} \mathrm{C}$ and holding for $20 \mathrm{~min}$ at a final temperature (it provides complete reduction of the magnetite phase of grain). II step - reduction of ilmenite phase with increasing temperature from $1300{ }^{\circ} \mathrm{C}$ to $1500{ }^{\circ} \mathrm{C}$ with holding at a final temperature of $5 \mathrm{~min}$. A one-stage resource-saving flow chart of titanomagnetite concentrate processing with a mass fraction up to $25 \%$ $\mathrm{TiO}_{2}$ has been developed based on carbothermal reduction of pellets in an annular hearth furnace. It allows to obtain two marketable products: granular cast iron $(92-96.5 \% \mathrm{Fe}, 3.4-3.7 \% \mathrm{C}, 0.5 \% \mathrm{~V})$ in $57 \%$ yield and titaniferous slag $\left(50-55 \% \mathrm{TiO}_{2}\right.$, up to $\left.7.4 \% \mathrm{FeO}\right)$ in $43 \%$ yield.

\section{References}

1. O. Zhbanova, L. Saitgareev, I. Skidin, N. Shapovalova, G. Gubin, Investigation of the Influence of Electro-Impulse Current on Manganiferous Liquid-Alloy, in: Advances in Design, Simulation and Manufacturing. DSMIE 2018 , ed. by V. Ivanov et al. Lecture Notes in Mechanical Engineering (Springer, Cham, 2019). doi:10.1007/978-3-319-93587-4_22

2. N. Berezhnoy, V. Chubenko, A. Khinotskaya, V. Chubenko, The increase in efficiency of strips production process in foundry and rolling mill stand. Metallurgical and Mining Industry 12, 296-300 (2015)

3. D.Yu. Baboshko, V.V. Tkach, L.N. Saitgareev, S.N. Zima, O.S. Vodennikova. Solid-phase metallization of a titanomagnetite site from phosphorus-titaniumiron ore of the Krapivensky deposit. Vestnik GGTU 3, 15-19 (2017)

4. G.B. Sadyhov, I.A. Karyazin. Researching of titanovanadium slags during the process of direct iron production from titanomagnetite concentrates. Metally 6, 3-12 (2007)

5. A.V. Asanov, A.V. Roschin, V.E. Roschin. Solidphase metallization of iron-vanadium concentrates obtained from titanomagnetite ores. Vestnik YuUrGU. Metallurgiya 13(189), 32-36 (2010)

6. D.S. Pogudin, G.B. Sadyhov, T.V. Olyunina, L.I. Leont'ev. Researching of one-stage process of metallization of titanomagnetite of the GremyakhaVermes deposit. Cvetnye metally 1, 73-76 (2011)

7. L.A. Mayorov, V.I. Serba, B.M. Freydin, I.G. Kolesnikova, Yu.V. Kuz'mich. High titanium titanomagnetite: features of technology and prospects of use. Titan 4, 4-9 (2009)

8. M.O. Oleynik, S.V. Mihno. Improving the reliability of the flow chart for the dressingt of the titanium ore of the Kropivensky deposit. Zbagachennya korisnih kopalin 48(89), 31-37 (2012)

9. L.V. Sklyar, T.A. Oleynik. Development of phosphorus-titanium ore dressing technologies of the Zhytomyr region (Mehanobrchermet, Krivoy Rog, 1996)

10. S.N. Zima, T.V. Bespoyasko, V.D. Docenko, Material composition \& physical and mechanical properties of the phosphorus-titanium-iron ore of the Kropivensky deposit (Zhytomyr region), in Novoe $v$ 
tehnologii i tehnike pererabotki mineral'nogo syr'ya (Mehanobrchermet, Krivoy Rog, 2007), pp. 34-40

11. S.N. Zima, Mineralogical-petrographic features of apatite-ilmenite-titanomagnetite ore of the Krapivensky deposit, in Novoe v tehnologii i tehnike pererabotki mineral'nogo syr'ya (Mehanobrchermet, Krivoy Rog, 2007), pp. 40-52

12. S.N. Zima, D.Yu. Baboshko, Features of titanomagnetite of the Krapivensky deposit in Volyn. Kazahstan Mining Journal 10, 4-7 (2015)

13. V.M. Kharitonov, O.V. Piskun, O.O. Kirichenko, Analysis of polishing and prosoric preparation of phosphorus-titanium ores of Kropivensky and Nosachivsky deposits of Ukraine. Heolohomineralohichnyi visnyk KNU 1(25), 74-83 (2011) 